\title{
ANÁLISIS DE LA REPRESENTACIÓN DE COLOMBIA EN EL ARCHIVO FILMOGRÁFICO ESPAÑOL "NO-DO"1
}

\section{ANALISYS OF THE REPRESENTATION OF COLOMBIA IN THE SPANISH FILM ARCHIVE "NO-DO"}

Por

Dino Ventolini Zuluaga ${ }^{2}$

Universidad de Córdoba, España. dino.ventolini@gmail.com

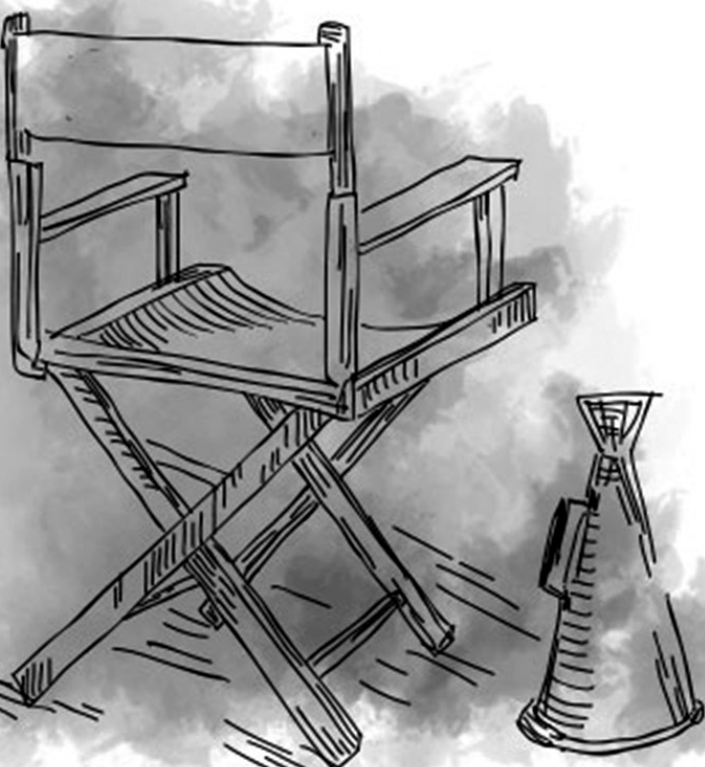


Resumen: Este artículo analiza la representación de Colombia en el archivo filmográfico español NO-DO. La selección de 18 filmes que mencionan o abordan temáticas colombianas, su análisis y sistematización por medio de una matriz, posibilitaron una lectura crítica y una propuesta de tres bloques temáticos que dejan entrever la imagen del país colombiano que se proyecta en este archivo, entre los años 1956 y 1976.

Palabras Clave: Representación, análisis cinematográfico, cine, archivo fílmico, memoria colectiva, documental.

Abstract: This paper analyses the representation of Colombia in the Spanish film archive NO-DO. The selection of 18 films that either approach Colombian subjects, their analysis and systematisation through a table, made possible a critical reading and a proposal of three thematical blocks that allow glimpsing the image of Colombia projected in this archive, between 1956 and 1976.

Keywords: Representation, cinematographic analysis, cinema, film archive, collective memory, documentary, Colombian cinema.

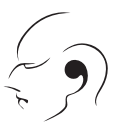

\section{Introducción:}

"El placer y el atractivo del filme documental residen en su capacidad para
hacer que cuestiones atemporales nos parezcan, literalmente, temas candentes"

(Nichols, 1997, p. 13).

Actualmente es posible consultar de manera digital uno de los archivos filmográficos más significativos del siglo XX y, tal vez, el más importante de España en relación con su memoria histórica: Noticiarios y Documentales NO-DO ${ }^{3}$. En este archivo, conservado y digitalizado por la Filmoteca Española y la RTVE, se pueden encontrar filmes de múltiples temáticas, territorios y momentos comprendidos en casi medio siglo de la historia mundial. 
El NO-DO, proyecto instituido por el régimen de Francisco Franco, consiguió que en todo el territorio español se exhibiera de manera obligatoria 4016 programas en las salas de cine, desde 1943 hasta 1975. Sólo hasta 1975 dejó de ser obligatorio su pase previo a cualquier película.

Estudiar al NO-DO desde el punto de vista cinematográfico permite entender, más allá de su composición o estructura técnica y de recursos audiovisuales, el trasfondo y el conjunto de significados, mitos e ideologías, entre otros hechos que con estos productos se pretendió crear. Es importante aportar elementos para pensar lo que representó y lo que todavía denota este archivo para la sociedad que lo presenció en el momento en que se hizo y para los nuevos espectadores que lo asumen desde un contexto anacrónico y muy diferente al de ese período. Pese a que han transcurrido más de 30 años desde el último capítulo de este noticiario, el archivo está conservado y disponible para continuar descifrando e interpretando cada una de esas piezas que pasaron de ser programas informativos de la actualidad de esa época, a convertirse en documentos valiosísimos que manifiestan la representación de una etapa de la historia española y de algunos eventos mundiales.

El Ministerio de Cultura de España, la Filmoteca Española y RTVE, tienen en su poder un archivo de gran importancia y valor para la sociedad. Las imágenes y sonidos de estas películas construyeron un imaginario y una historia que se reprodujo buena parte del siglo XX en millones de personas y que hoy, debido a su disponibilidad en internet, aparece nuevamente con un propósito diferente y sin fronteras.

La facilidad de consultarlo en línea permite que se revise el material desde múltiples perspectivas y con infinitos propósitos. Una de ellas, la que formula este artículo, permite encontrar un trozo del patrimonio que hace referencia a Colombia; una versión de su historia contada desde el lenguaje cinematográfico y con una mirada foránea. La representación de un país por medio de piezas noticiosas o documentales.

Hay múltiples elementos y puntos de vista que invitan a pensar lo que representó -y lo que todavía denota- este archivo para la sociedad que lo presenció, pues, como aclara Busto Miramontes (2012): "las estructuras, símbolos, metáforas, que se ven en NO-DO pretendían generar significados mucho más allá de los seres mismos que desempeñan la acción; en aquellos que se suponen seres pasivos, y que no lo son: los espectadores" (p.3).

Tanto en películas de Hollywood como en cualquier texto cinematográfico, por medio del análisis fílmico se pueden encontrar pistas y detalles que cambian la lectura e interpretación de un filme. Así, este análisis fílmico se convierte en un "instrumento de trabajo fundamental para las claves que explican la eficacia, subrepticia u 'oculta' a menudo, de los mensajes que encierran los textos cinematográficos” (Marzal y Gómez, 2006, p.2). Es muy útil y apropiado investigar o proponer lecturas juiciosas acerca de estos filmes; convertirlos en documentos que propicien la participación 
y la interpretación por medio de relaciones y conjeturas que permitan entender esas imágenes desde su conjunto y no como piezas individuales de un pasado que se reduce a lo anecdótico.

Históricamente, los estudios sobre cinematografía han privilegiado las grandes obras y las películas de ficción, mayoritariamente; en cambio, el documental o las películas de no-ficción y los archivos filmográficos han quedado relegados a unos pocos estudios. Siguiendo esta tendencia, están los archivos del NO-DO. Aunque sí existe un número importante de publicaciones alrededor de sus productos, sobre todo dirigidas a temáticas particulares o momentos específicos, hay un universo inmenso que está inexplorado y que reposa en las estanterías o en las unidades de almacenamiento virtual y servidores de la Filmoteca. Para la misma Filmoteca Española (2015), este archivo significa: "el mayor patrimonio audiovisual de España”.

Al ser testimonios de procesos históricos, estos noticiarios y documentales llegan a convertirse en un discurso y en un documento para estudiar un pasado; permiten ver y comparar uno de esos discursos que se construyeron de realidad. Aunque no exista la realidad, sí hubo aproximación y una imagen reproducida de ésta que caló en muchas personas (Gavaldà, Llorca y Peris, 2013). Como piezas cinematográficas, se pueden considerar desde la construcción de su forma, pero también desde lo que contienen, su discurso; como documentales que, teorizado por Bill Nichols (1997): "no difieren de las ficciones en su construcción como textos sino en las representaciones que hacen” (p.155).

Cada elemento que los compone tiene una carga de subjetividad que lo convierte en un artificio, en un discurso retórico; en una realidad que no fue captada sino representada. Este texto comparte también la necesidad de Fibla Gutiérrez (2015) de "interrogar estas imágenes, no sólo desde el ámbito académico sino también desde la interpelación creativa, permitiendo que las respuestas salgan a la luz tras décadas de existencia subterránea” (p.4).

Hasta el momento en que se escribió este artículo, no se encuentra ninguna propuesta de análisis que se interese por la relación o la presencia de Colombia en la filmografía del $N O-D O$. Aunque también es fácil advertir que no es una carencia propia de la producción audiovisual, pues también es muy escasa la producción bibliográfica dedicada al patrimonio audiovisual colombiano o referente a este país. Como aseguran Gutiérrez y Aguilera (2002): "el documental, medio privilegiado para recuperar y activar la memoria, carece de su propia memoria" (p.22). 


\section{Metodología}

Por medio de la descripción y análisis de 18 filmes del archivo NO-DO, realizados entre 1956 y 1976, se trata de dar cuenta de la representación de Colombia. Se acude a la identificación y sistematización de las preocupaciones e intereses temáticos, así como la manera en que se produjeron estos noticiarios, reportajes o documentales. Se enfatiza en un análisis textual y descriptivo del filme, pero se tiene en cuenta la complejidad y el contexto histórico en el que se realizó. Parte de esa complejidad, conceptualizada por Aumont y Marie (1998), comprende al filme como una obra artística autónoma que puede examinarse desde análisis textual, narratológico, icónico y psicoanalítico. También se comparte el supuesto de Marzal y Gómez (2007) que dice que "para analizar un film no es suficiente verlo; la relación que se establece con el objeto en cuestión requiere una aproximación en profundidad que obliga a revisitarlo hasta llegar a sus resortes mínimos" (p.2).

Lo anterior reúne elementos significativos del filme que se tendrán en cuenta en esta propuesta; aspectos como el texto (audiovisual), las significaciones narrativas, los aspectos de forma, visuales y sonoros y los juicios críticos o las reacciones que produce o que sugiere sobre los espectadores. Es decir, un compendio de elementos multidimensionales (objetivables y no objetivables) que engloban la concepción de análisis fílmico (Gómez, 2006, p.4).

Las limitaciones y condiciones de realización de estos filmes los convierten en prácticas institucionales y productos que representaron una realidad. Esa definición y clasificación que Bill Nichols formuló sobre el documental expositivo clásico, es también adherida al desarrollo de este estudio, en la medida en que están todos producidos bajo un modelo en torno a una lógica informativa en la que "la responsabilidad del realizador es hacer que su argumentación resulte tan exacta y convincente como sea posible, aunque ello requiera la recontextualización de las afirmaciones de testigos o expertos individuales" (Nichols, 1997, p.47).

Estas piezas cinematográficas son entendidas también como discursos, siguiendo la perspectiva de Marc Angenot recogida en la tesis doctoral de Rubén Dittus, que sugiere que "discurso es todo lo que se escribe y se dice en una sociedad, hechos que funcionan independientemente de los usos que cada uno les atribuye y que, por tanto, existen fuera de las conciencias individuales" (Dittus, 2012, p.267).

Se propone una sistematización individual de cada pieza, con sus características y elementos y, posteriormente, se revisan en conjunto para encontrar relaciones y asociaciones que las sitúen como verdaderos objetos de investigación. Esto, avalando la actualizada propuesta de (Dittus, 2012), que plantea que los textos fílmicos, como objeto de estudio, "no pueden ser excluidos o diseccionados ignorando el discurso principal. Dichos fenómenos existen en un espacio y tiempo particular, y sólo desde allí son asumidos como nítidos objetos de investigación” (p.266). 
Estos aportes de procedimiento, más el abordaje de Nichols sobre el rol del filme documental, terminan de completar esta propuesta metodológica, que coincide con la definición de este último autor que relaciona la representación de la realidad con "significados y valores, interpretaciones y objetivos, no sencillamente con signos y sistemas (...). Los valores que defendemos, los significados que asignamos, las interpretaciones que ofrecemos y las metas que perseguimos tienen consecuencias. Hacen que ocurran cosas" (Nichols, 1997, p.19).

Es posible entonces describir, analizar y diseccionar cada nota de noticiario o documental del NO-DO como textos documentales que son, pues, como asegura Matud (2008): "aunque los documentales nos dirigen hacia el mundo, siguen siendo textos. Por tanto, comparten todas las implicaciones del status construido, formal e ideológicamente modulado, de la ficción" (p.5).

No obstante, la comprensión o consideraciones que se sugieren están amparadas en la modificación de las condiciones de visión del filme que permite el análisis pausado y en frío; no es igual ver un filme una única vez en una sala de cine, que tener la posibilidad de pausarlo, ralentizarlo y repetirlo cuantas veces se quiera.

El estudio está distribuido en tres momentos. El primero y más robusto, que tiene que ver con la revisión del contenido de cada una de las 18 piezas; seguido de una sección de descripción y sistematización de cada una en una ficha o instrumento de análisis y finalmente un análisis, a partir de la interpretación, comparación y conclusión de los documentos aludidos. No obstante, hay que aclarar que el aporte fundamental es la descripción y sistematización.

La selección fue realizada por medio del buscador de la plataforma online de la Filmoteca Española y $\mathrm{RTVE}^{4}$, que reúne más de 2500 capítulos del NO-DO, para ser consultados y visionados por cualquier persona. Se hizo una búsqueda con palabras clave como Colombia, América Latina, América del Sur, Bogotá o Suramérica, en la sección de Archivo Histórico (Figura 1).

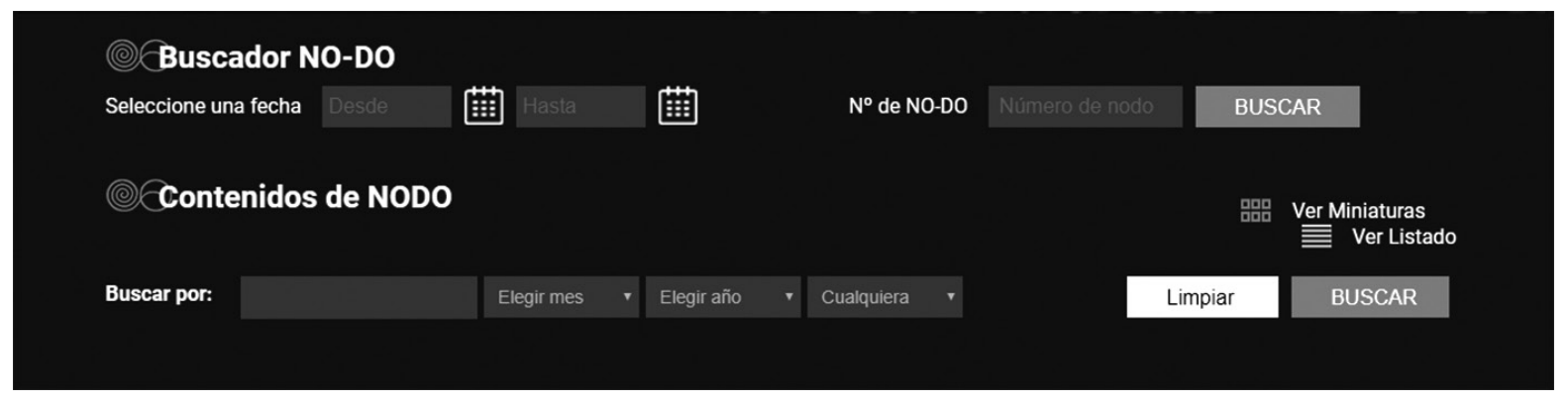

Figura 1. 
Para sistematizar los documentos revisados y dinamizar la lectura de los noticiarios, se propuso una matriz de análisis, estructurada con información de catalogación o descripción, forma y contenido. La matriz fue validada por los investigadores y expertos en cine Ana Melendo Cruz y Ramiro Arbeláez Ramos ${ }^{6}$.

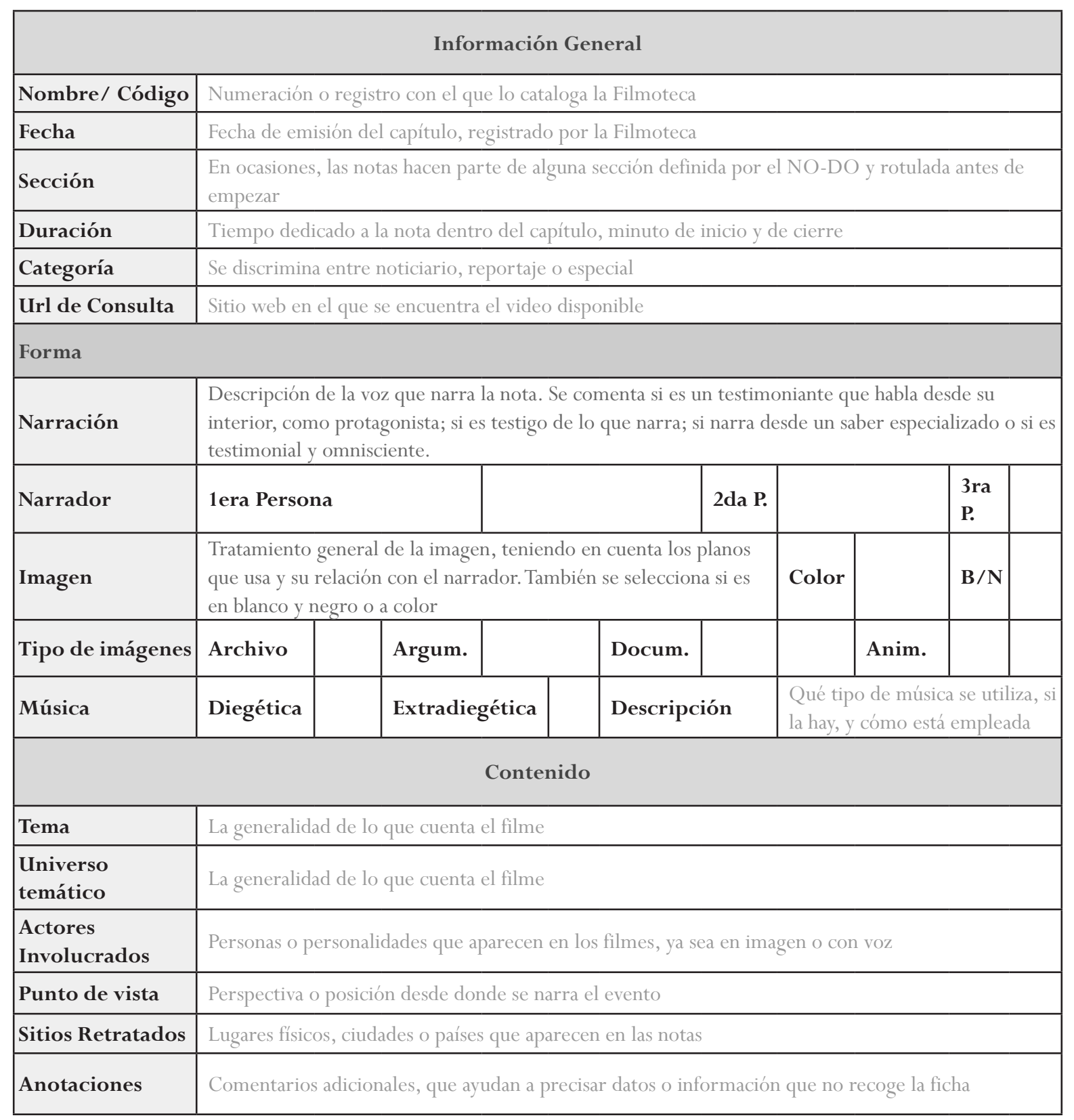

Tabla 1. 


\section{Desarrollo:}

\subsection{Un archivo audiovisual como memoria colectiva:}

Así como en la construcción social de la historia, estos documentos audiovisuales también inciden en la memoria colectiva. Siguiendo presupuestos conceptuales de varias disciplinas, se puede pensar que este noticiario contribuyó y seguirá contribuyendo a la creación de una memoria colectiva o, por lo menos, sirve como articulador de hechos pasados y vividos que tendrán significación en la gente. Debido a que los capítulos del NO-DO examinados para este texto contienen relatos filmados tanto en España como en Colombia y perduraron hasta la actualidad, con posibilidad de ser consultados desde cualquier sitio, esa memoria se implanta en varios escenarios. Es decir, que funciona diferente en las personas que los vieron en las salas españolas el año de producción, a las que los observan posteriormente en internet y los que los conocen en Colombia 40 años después, por ejemplo. Esa memoria o recuerdos que, como plantea Barrios (2013):

... se construyen desde el presente, de acuerdo a las visiones de mundo que comparte el grupo de pertenencia donde el individuo se inserta y del que forma parte, entendiéndose este como una comunidad de sentido, de afectos y compromisos que se debate entre recuerdos y olvidos. Comunidad que se proyecta hacia el futuro al mismo tiempo que recuerda (p. 389).

El NO-DO se podría entender como ordenador de memoria colectiva y recuerdo, en tanto incide en la atribución de significados y sentidos. Tiene que ver con los procesos de significación, que se vuelven memoria, cuando "confieren al pasado un sentido que concuerda, otorga coherencia y continuidad al presente, incidiendo de esa forma en la estructuración de un futuro expectante” (Cervio, 2010, p.72). Así entonces, este texto, sin querer alardear de ser un argumento de la importancia del NO-DO en términos de patrimonio cinematográfico, sí propone enmarcarlo como documento audiovisual, en la calidad de articulador de memoria colectiva, representación de realidad e historia de la sociedad. Cabe aclarar que el NO-DO no sólo fue una producción audiovisual de obligatorio consumo, sino que también tuvo exclusividad para narrar de manera oficial lo que sucedía en esa etapa de la historia.

\subsection{Nacimiento del NO-DO:}

Durante uno de los momentos más difíciles de la era moderna de España, marcada por conflictos, guerras y una prolongada dictadura, nació una entidad que acompañó por más de tres décadas la cotidianidad de los ciudadanos españoles: el NO-DO.

Emergió en un contexto dominado por constantes cambios y ambiciones combativas, que además estuvo enmarcado por relevantes momentos como el franquismo y la Segunda Guerra Mundial. Un grupo de unas 60 personas, luego del verano de 1942, 
empezaron a trabajar en el proyecto para la creación de un noticiario que sirviera como aparato de propaganda del gobierno y como tenue hilo de unión entre los españoles y la realidad circundante. Inició gracias a una orden de la Vicesecretaría de Educación Popular del gobierno de Franco que creó la entidad de Noticiaros y Documentales el NO-DO, el 29 de septiembre de 1942 (Televisión Española S.A., 2013). A partir de ahí, todo el que fue al cine tuvo que ver el NO-DO, cada vez que fue. Una generación completa participó.

En ese momento ir a cine era una actividad concurrida, no sólo porque era un espacio para evadir la crisis y la realidad que se estaba viviendo, sino por lo acogedoras y cálidas que eran las salas de proyección. A esa España, con gentes agotadas, con tragedias recientes y con las esperanzas debilitadas, se le ofrecía fragmentos de una realidad que era la única posible y un contacto con el resto del mundo que parecía veraz. Como versa el lema de sus rótulos, se ofrecía "el mundo entero al alcance de los españoles" (Figura 2).

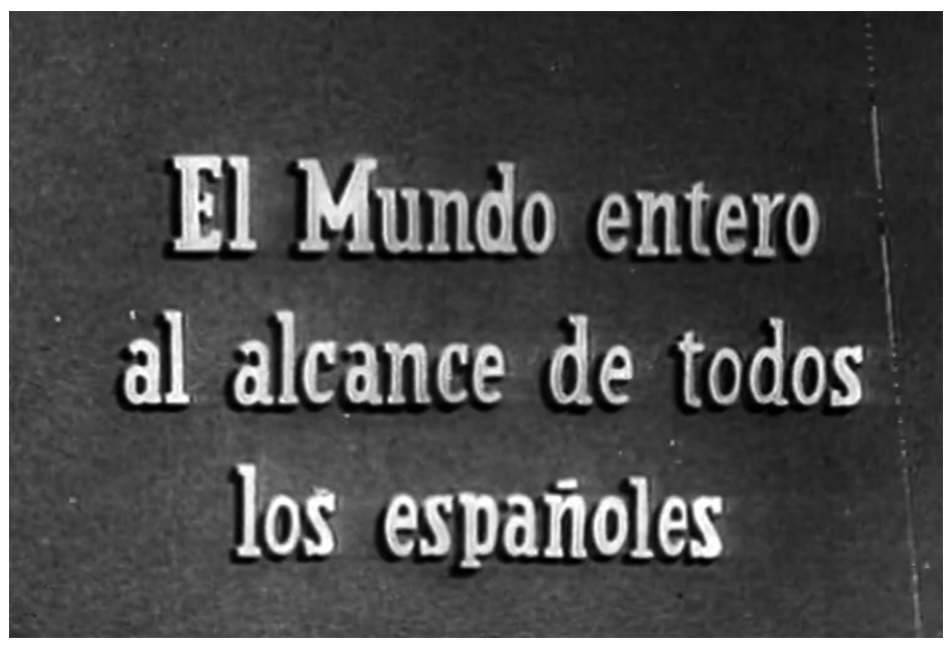

Figura 2: Lema del Noticiario

La televisión no existía y, para mucha gente, la única manera de acceder a información noticiosa con imágenes en movimiento era a través del NO-DO. Este fue el primer referente continuo de cultura gráfica para la sociedad española, que de manera prolongada retrató lo que sucedía en los rincones del país y en algunos territorios extranjeros. Asimismo, fue este noticiario el que, como propone (Ventajas, 2006): "suprimió la habitual proyección de los noticiarios extranjeros -el hispano-alemán Actualidades UFA, el norteamericano de la Fox y el italiano LUCE, entre otros-” (p.1).

Fue así como el 4 de enero de 1943 se proyectó el primer número del NO-DO (Figura 3). "Una pantalla iluminada que hablaba de otras vidas; de otros hombres y mujeres que no pasaban privaciones; de playas californianas donde el cine no existía” (Fandiño, 2009, p.22). 


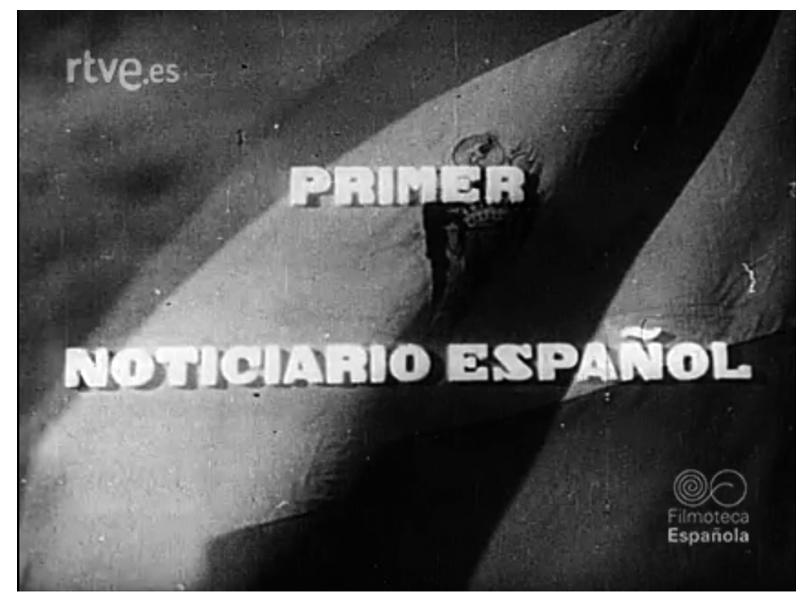

Figura 3: Captura del primer capítulo

\subsection{La realidad del Régimen:}

Sobre la imagen de país que se proyectaba en los noticiarios, es bastante evidente que estaba marcado por la parcialidad y por una decisión consciente sobre lo que se pretendía lograr. No sólo hubo una selección clara de las actividades, procesos y eventos que se querían contar, sino que también se definió la manera como se contaría para evitar evidenciar ciertos aspectos de la realidad que vivía el país.

Tanto la simbología gráfica como el discurso del narrador del noticiero, construyen un imaginario histórico que se va infiltrando progresivamente y contribuyendo a la perpetuación del régimen franquista como entidad inevitable:

si nos atenemos al contexto histórico de la España de posguerra, en donde la televisión habría de esperar hasta mediados de los años sesenta para popularizarse en los hogares españoles, y el cine era la única pantalla disponible, la importancia del NO-DO como aparato ideológico institutivo del franquismo resulta fundamental (Fibla, 20015, p.4).

Era una intención clara de construir un imaginario que no se correspondía con el día a día de las familias españolas. Una imagen "de un tiempo histórico detenido, inamovible, ajeno a la realidad y recreando una vez tras otra los mitos de una España religiosa e imperial” (Sánchez y Tranche, 2002, p. 206).

En ese propósito de construcción de la España anacrónica, se tenía todo presupuestado para rendir cuentas al proyecto del Régimen. Tanto el cine de ficción como el cine documental, del cual el NO-DO era productor exclusivo, estaban sometidos a una revisión de sensores que filtraban, mutilaban o autorizaban cualquier obra que se proyectase en España (Figura 4). 


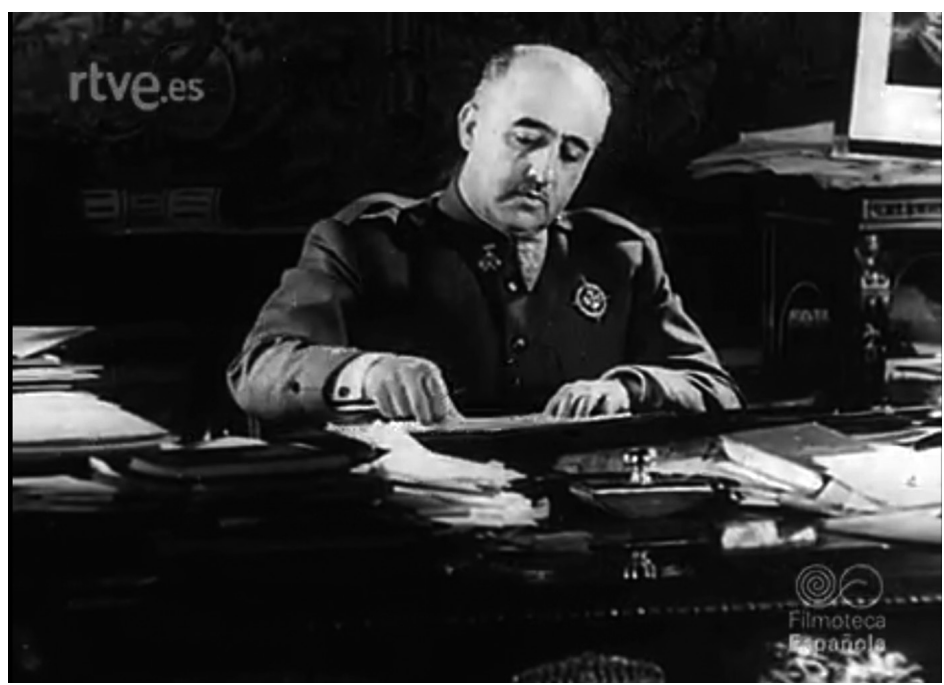

Figura 4: Franco, en primer capítulo del NO-DO

\subsection{El archivo filmográfico como patrimonio:}

"No podremos entender nuestro siglo si nos falta la visión cinematográfica de él" Ángel Luis Hueso (1998, p.39).

El cine, producido en el Siglo XX, puede usarse, según Martínez (2013): "como una fuente tanto secundaria (pues elabora un discurso sobre una época) y como primaria (es producto de la época en que la película se gesta)" (p.364). En el caso del archivo NO-DO, es también un documento de gran valor histórico, como elemento clave en la construcción de país y en el conjunto de textos que componen la cultura del pueblo español o su imaginario colectivo. "Y es que las Ciencias de la Etnografía y la Antropología comienzan a usar el cine desde prácticamente sus orígenes como un instrumento más junto con la cámara fotográfica y el registrador de sonidos" (Domínguez-Delgado y López-Hernández, 2016, p.18).

Como diría el documentalista chileno Patricio Guzmán: "un país sin cine documental es como una familia sin álbum de fotografías" , y en parte, ese es el devenir del archivo para las nuevas generaciones.

Como propone Martínez (2013), a partir de la revisión bibliográfica existente sobre el tema:

El cine no sólo se hace eco de la Historia, sino que la representa, fabrica Historia; y, más aún, también lo hace de un modo ontológico, pues toda imagen filmada se convierte ipso facto en pasado. El cine, en fin, no puede entenderse sin los condicionantes sociales en que se desenvuelve y evoluciona con ellos contribuyendo a alumbrar la sociedad de la imagen, antes escasa y elitista, pero que en el siglo XX se generaliza hasta hacerse omnipresente (p.353). 
No obstante, los archivos cinematográficos tienen mucha vocación como elementos de la historia, pues, como concluye (Martínez, 2013, p. 368), cada archivo o película "no se limita a ser un documento histórico, sino que es también un agente de la historia, o sea, es capaz de crear o contribuir a crear el acontecimiento" o dicho en palabras de Sorlin (1996), "los filmes exhiben aspectos de la sociedad que los produce" (p.23).

\section{Análisis de Colombia en el NO-DO:}

"Las imágenes gestionan la estructuración de nuestro imaginario" (Català, 2012, p.193).

\subsection{Bloque $\mathrm{N}^{\circ} 1$ : Colombia, un pueblo que requiere ayuda:}

Capítulo 1: N 694-B (23-04-1956)

Está dedicada a la instalación de Radio Sutatenza, una iniciativa comunitaria de la Unesco para mejorar la educación en zonas rurales de Colombia. La pieza fílmica está construida en exteriores, con planos cercanos (primeros planos y planos medios) que son usados según el motivo. Se recurre a primeros planos cuando se muestran los equipos y la infraestructura de la radio, como también cuando se habla de los educadores, instructores y operarios de las máquinas. Cuando se mencionan a los niños y la comunidad que recibe las capacitaciones, son fotografiados en grupos numerosos, con planos amplios (planos generales) y distancias lejanas (Figura 5.), sólo hay un par de primeros planos de rostros de locales. También hay uso de movimientos de cámara y un plano aéreo que muestra el contexto del sitio.

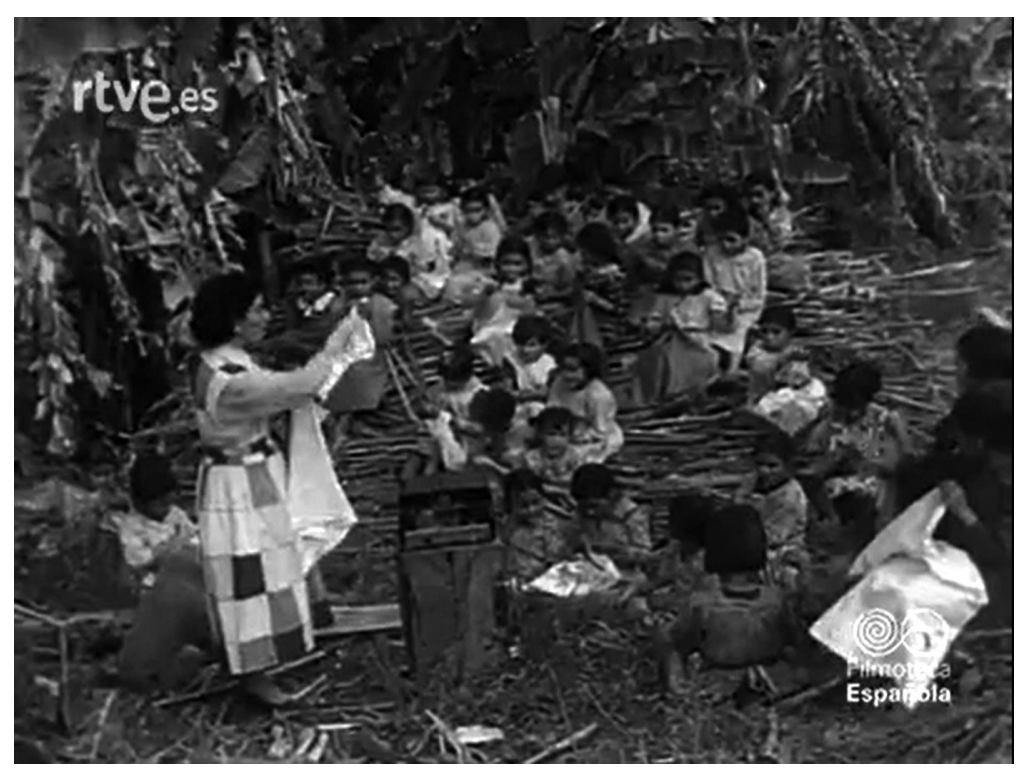

Figura 5. 
La narración es una voz en off omnisciente que va anticipando las imágenes y presenta la información con tono imparcial, pero alabando la labor de las capacitaciones de los extranjeros y miembros de la Unesco, al tiempo que va manteniendo una voz oficial: "el sistema resulta también útil para la enseñanza de labores a las pequeñuelas"..."de los 12 millones de habitantes de Colombia, ocho millones residen en el campo y se sirven de la radio gracias a la influencia beneficiosa de la UNESCO. El presidente de Colombia, General Rojas Pinilla, ha visitado atentamente el desenvolvimiento de estos cursos".

Capítulo 2: $\mathrm{N}^{\circ}$ 712-B (27-08-1956)

Contiene dos notas dedicadas al país colombiano, rotuladas con el titular "Actualidad de Colombia". En la primera, se da cuenta de las exploraciones y excavaciones petroliferas en las selvas colombianas, por parte de empresas norteamericanas. La segunda, narra la tragedia ocurrida en la ciudad de Cali, por la explosión de siete camiones del ejército cargados con dinamita.

Mientras que la primera tiene como objetivo relatar que unas expediciones de expertos norteamericanos van a sacar provecho de los "importantes yacimientos del preciado combustible líquido", en la segunda los protagonistas son el pueblo colombiano como víctima de la explosión. Ambas notas están narradas como hecho noticioso, pero los actores involucrados y la manera de construir el texto audiovisual son diferentes. Mientras en la primera se destaca la experticia de los operarios y la dotación de recursos técnicos de la delegación extranjera, en la nota del accidente la atención se centra en el evento catastrófico y en los destrozos causados.

Desde la forma y la imagen, ambas notas difieren en su tratamiento. La primera se monta con planos de múltiples encuadres, alternando tamaños de cuadro entre primeros planos, planos medios y planos generales (Figura 6); con cámara en trípode y movimientos pausados y variados que están armonizados con una música alegre, incluso se utilizan planos aéreos y un montaje rápido, con cortes rápidos. La segunda acude a planos generales y medios (Figura 7) y movimientos con cámara en mano. Sólo se hace un plano cercano cuando se menciona al presidente de Colombia y las autoridades que lo acompañan; toda la información está dirigida y antepuesta por la voz del narrador. La nota está acompañada de música rápida que refuerza el desconcierto y desorden de las gentes involucradas en el evento.

Figura 6 y 7.
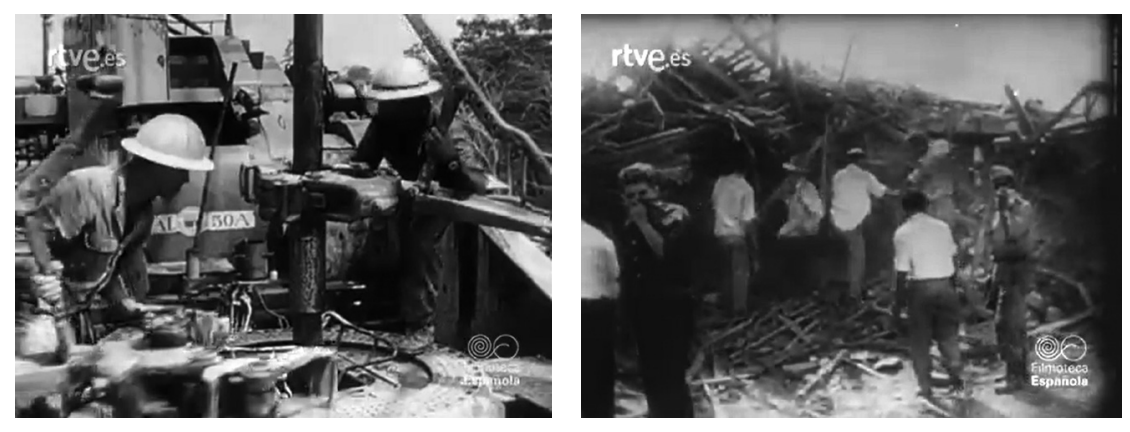
Rotulada como “Instantáneas Mundiales”, simplemente cuenta la llegada del hombre más viejo del mundo a Nueva York (Figura 8). Se anuncia que es colombiano y se llama Javier Pereira.

Este filme va contando la noticia a medida que el encuadre de los planos se va cerrando, comenzando con un plano general de la llegada y el contexto del aeropuerto, hasta llegar al primer plano del personaje que se menciona. Aunque la nota se queda en el plano de lo fortuito, el narrador sí interviene para aportar un tono cómico a la noticia, al decir que es un colombiano que "dice tener 167 años de edad y que, después de su vuelo, da prueba de su energía y de su mal genio". Toda la nota es acompañada de música animada y no hay intervención directa de ningún actor.

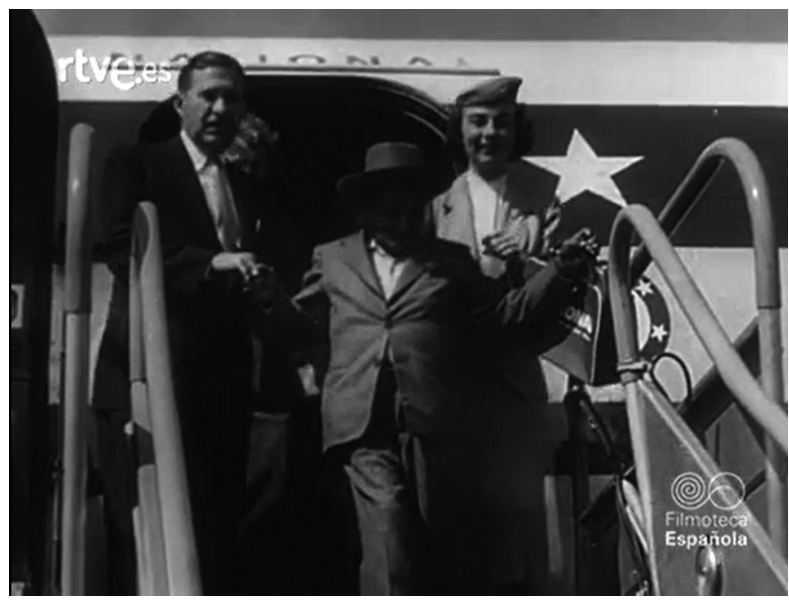

Figura 8.

Capítulo 4: $\mathrm{N}^{\circ}$ 865-B (03-08-1959)

Se informa de las inundaciones causadas por fuertes lluvias en un pueblo colombiano. Se destacan los daños y víctimas causadas por las inundaciones y se limita a la información de lo ocurrido.

La nota es fotografiada utilizando planos generales en los que no se distingue ninguna persona, a excepción de un par de planos en los que se ve al equipo de primeros auxilios médicos; la cámara siempre lejos y desde una angulación en picada (Figura 9). Mientras la música le proporciona tensión a las imágenes, la cámara hace movimientos que engrandecen la catástrofe. Por su parte, el narrador informa de las cifras de afectados y los daños causados y se vale de algunas valoraciones que le dan más dramatismo al evento: "víctimas de las inundaciones, los habitantes supervivientes de humildes poblados de la Comarca de Tolima, en Colombia, abandonan la zona afectada por la catástrofe". 


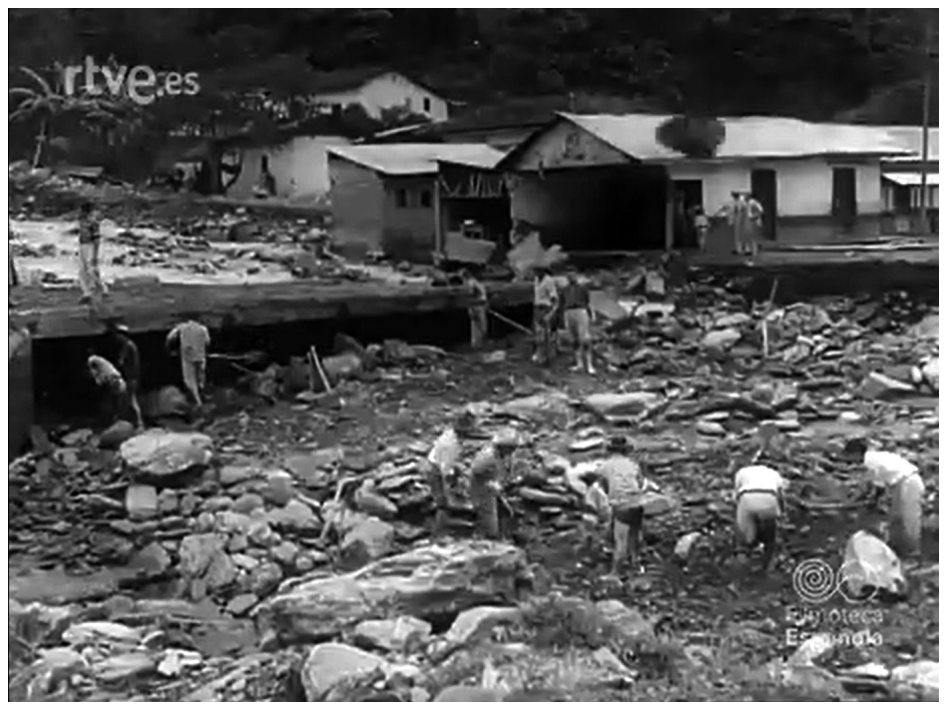

Figura 9.

\subsubsection{Observaciones generales del Bloque 1:}

En este primer bloque se ubican los capítulos realizados durante la década del cincuenta. Cuatro capítulos emitidos en 1956 y 1959 que abarcan cinco notas dedicadas a Colombia, en las que se cubren hechos noticiosos en territorio colombiano que percibe un país urgido de asistencias externas. La construcción de los filmes denota un país que requiere intervenciones, que vive necesidades y angustias, por lo que tiene que ser ayudado para salir adelante. Los protagonistas son las personalidades políticas y el discurso narrativo contiene aseveraciones prejuiciosas, tanto en el plano textual de un narrador omnisciente, como en el lenguaje cinematográfico y las consideraciones estéticas. También es frecuente, en casi todos los capítulos, la presencia de un narrador enunciativo, que se dirige a los espectadores de modo directo, hablando con ellos o haciendo reflexiones compartidas.

En general, estos capítulos enseñan al país colombiano como arquetipo de nación subdesarrollada, rural e inculta, azotada por catástrofes. En el discurso se perciben gentes o poblaciones que requieren ayuda, grupos de individuos en medio de grandes paisajes y agrestes territorios que luchan contra infortunios. Están casi invisibilizados. En general, no hay planos cercanos, ni intervenciones de su parte; tampoco se hace mención de ellos ni de sus nombres.

Lo que protagoniza las notas son los eventos o la cuota extranjera de apoyo. Cuando se menciona al país colombiano es sólo para ubicar geográficamente la situación o el evento, más no hay contexto o precisiones al respecto. 


\title{
4.2 Bloque $\mathrm{N}^{\circ}$ 2: España provee herramientas de desarrollo a Colombia:
}

\author{
Capítulo 5: $\mathrm{N}^{\circ}$ 964-B (26-06-1961)
}

Cuenta la visita del ministro de trabajo de Colombia, José Elías del Hierro, a la sede central del Instituto Nacional de Previsión de España. La narración enfatiza en el interés del ministro colombiano por las experiencias de la entidad española, asegurando que: "en el amplio y cordial cambio de impresiones, el señor Elías del Hierro se mostró muy interesado por la obra social realizada en España”.

La mayoría de la información de la nota está proporcionada por la voz del narrador, es la que dirige las imágenes y va anunciando quiénes aparecen. Por su parte, la imagen únicamente hace primeros planos y planos medios de las personas que asisten a la reunión. Los planos son alternados por tamaños de encuadre y por diferentes personalidades políticas que participan de la reunión, sonrientes y rodeados por cámaras que los fotografían (Figura 10).

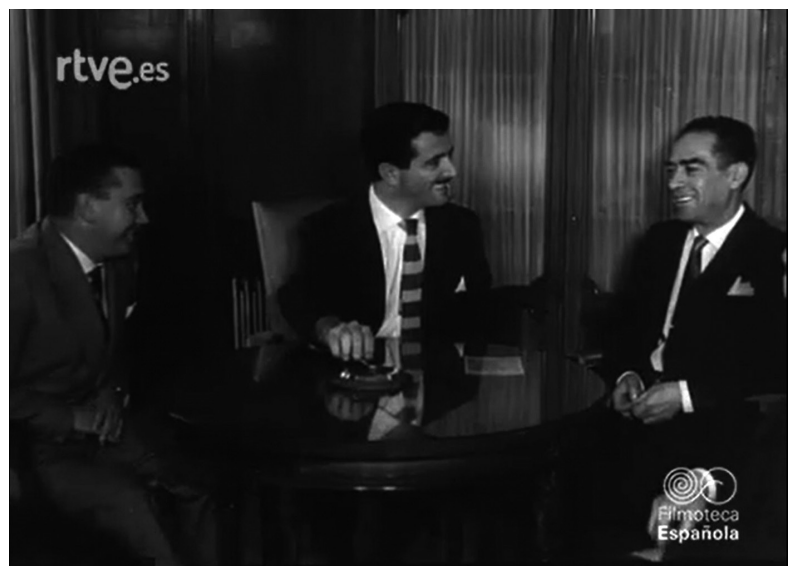

\section{Figura 10}

Capítulo 6: N 969-C (26-06-1961)

Contiene una nota que cubre la noticia de una operación para llevar víveres y herramientas a la tribu de los Motilones, en la selva colombiana, por parte de la Sección de Asuntos Indígenas del Gobierno de Colombia. La construcción de la nota está compuesta por una voz en off que dice en qué consiste la operación e imágenes de los preparativos y la ejecución de la entrega de los víveres desde un avión. Las acciones están organizadas y estructuradas de manera cronológica y con todos los momentos del procedimiento: desde la planificación en tierra, hasta el lanzamiento de los paquetes desde el aire a los territorios de los indígenas. Todo está filmado desde la perspectiva de los funcionarios que lideran la operación y nunca se muestran los actores "beneficiados" por la ayuda (Figura 11). La única alusión a los Motilones la hace el narrador, comentando de manera peyorativa quiénes son: 
La sección de asuntos indígenas del Gobierno de Colombia, efectúa por primera vez en la historia del país una operación de ayuda desde el aire a los Motilones, raza de feroces indígenas que viven ocultos en la selva y que hasta ahora han reuhído todo contacto con la civilización de los blancos, pues los consideran enemigos.

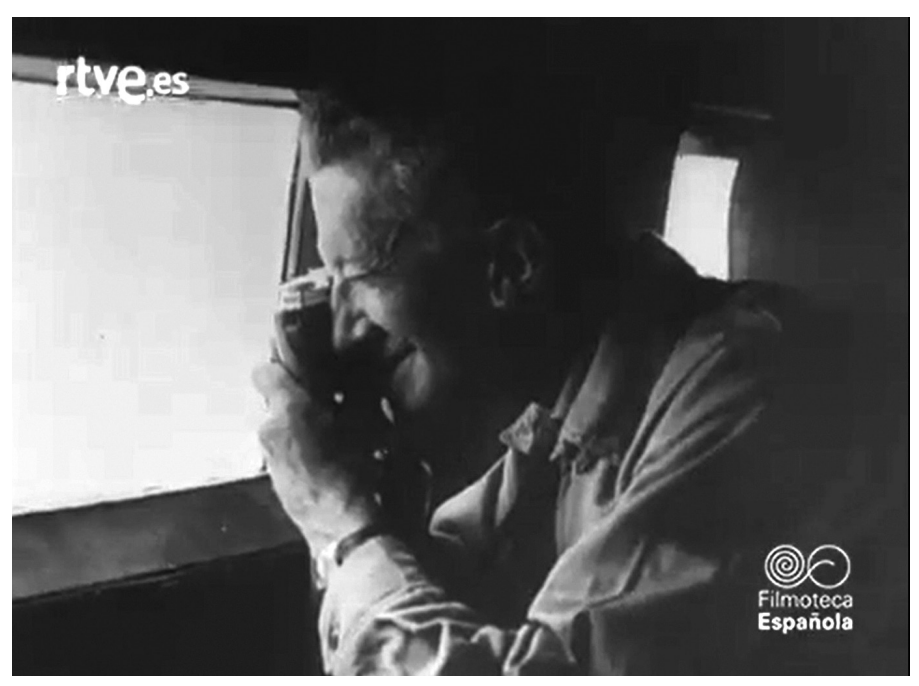

Figura 11.

Capítulo 7: N 980-B (16-10-1961)

Está dedicada al envío de un lote de automóviles a Colombia por parte de la industria española. La mercancía es la que protagoniza el discurso y el narrador constantemente alardea sobre las capacidades de los automóviles y de la industria española que los fabrica: "Estos coches son para todo terreno, (...) muestra las grandes posibilidades ofrecidas a la industria española en el mercado hispanoamericano”. La imagen y el sonido (música) están empleados de manera conjunta para recrear una alegre secuencia del embarque de la mercancía (Figura 12). Es una especie de coreografía que deja ver la eficiencia de las herramientas y el trabajo del puerto español, en la que los autos danzan al ritmo de la música, con múltiples tamaños de plano y emplazamientos, así como algunos movimientos de cámara que siguen a los autos.

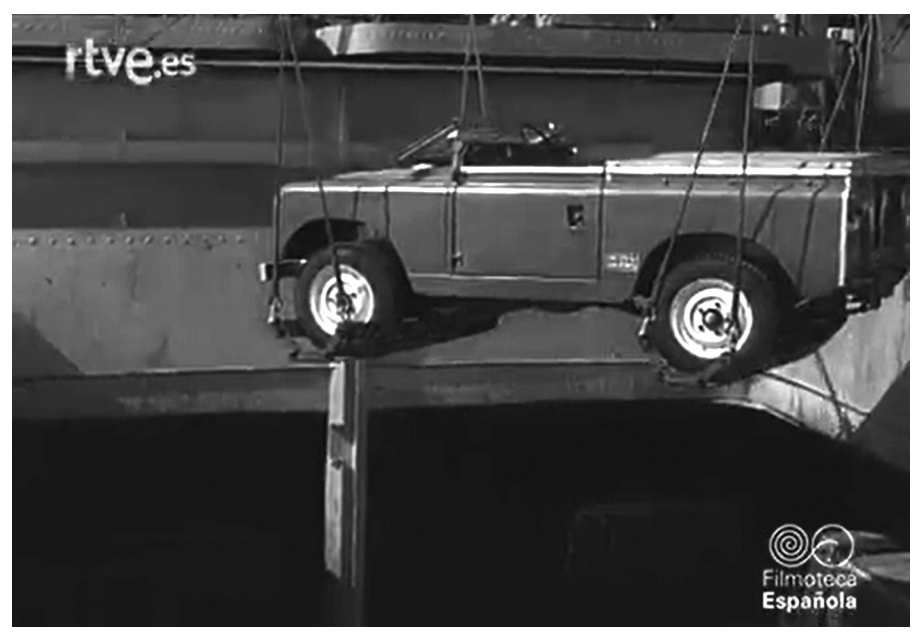

Figura 12. 
Capítulo 8: N 992-C (08-01-1962)

Marcada como "noticias mundiales", la nota está dedicada a la visita del presidente de los Estados Unidos, John F. Kennedy, a Venezuela y Colombia. Está construida desde la perspectiva de la delegación visitante, tanto desde el discurso del narrador en off, como desde las imágenes y el sonido que acompañan todo el tiempo al presidente. Desde su llegada en el avión presidencial, la cámara lo acompaña en todo momento (viajando en su avión, en el encuentro con los presidentes, en el discurso, en el tour por la ciudad en automóvil). Sin duda el protagonismo se lo lleva la delegación de los Estados Unidos y los dos presidentes que lo reciben en cada país; inclusive se le da voz e imagen a la primera dama, Jacqueline Kennedy, para escuchar sus palabras: "Estas cosas deberían estar al alcance de todos y no limitarse a unos pocos afortunados" (Figura 13).

El filme selecciona los momentos más importantes de su visita y muestra el entusiasmo de las masas que lo reciben. Con planos cercanos y movimientos de cámara, se retrata al presidente y a su esposa; los grupos de personas locales son retratados en masas, con planos picados generales (figura 14).
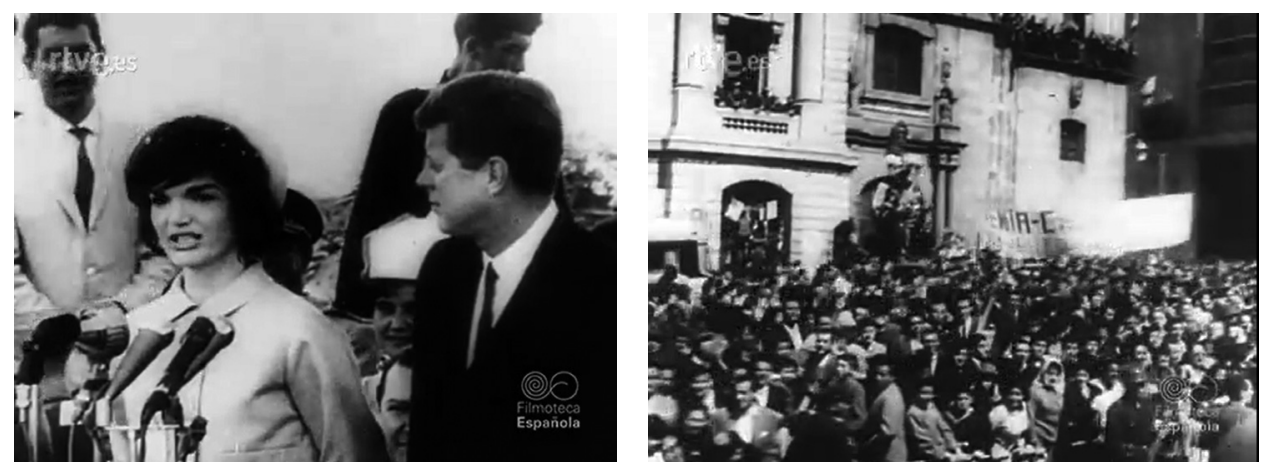

Figuras 13 y 14 .

Capítulo 9: N 994-A (22-01-1962)

El filme recoge una nota sobre la producción y exportación de transformadores eléctricos españoles para varias ciudades de Colombia. Guiada por la voz del narrador, la noticia cuenta la manera en que se producen, los componentes que tienen y las características que los cualifican. Tanto la voz en off como las imágenes se encargan de enaltecer y destacar la calidad de los transformadores españoles: "Son transformadores de condiciones especiales, concebidos y fabricados para ser instalados en la intemperie (...)”. 
De manera cronológica y pasando por todas las etapas de producción, la nota va mostrando el proceso desde que se fabrican las piezas de los transformadores en la fábrica, pasando por el ensamblaje, embalaje y embarque (Figura 15). El filme está construido como un vals que va de paso en paso moviendo los transformadores al son de la música de fondo, en el que las maquinarias y sus operarios son destacados: primeros planos cuando se enfatiza en la tecnología y planos generales para mostrar la dimensión del embarque.

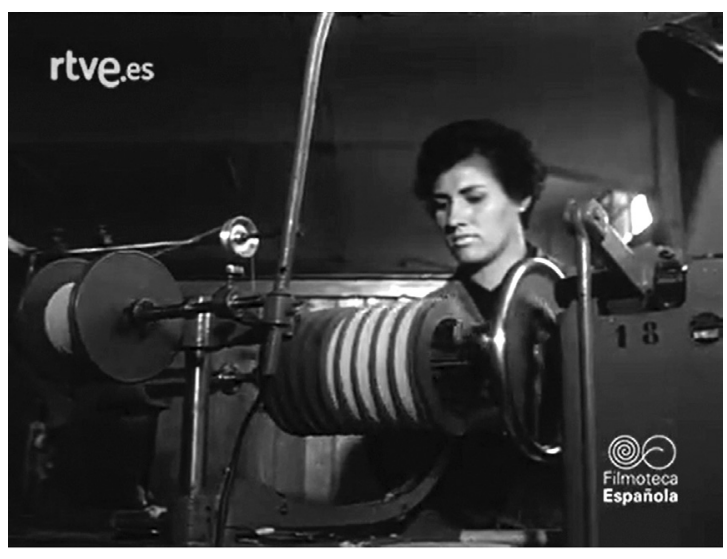

Figura 15.

Capítulo 10: $\mathrm{N}^{\circ}$ 1364-A (24-02-1969)

Se anuncia la importación de cuatro locomotoras españolas a la capital de Colombia. La nota, rotulada como "noticias breves", registra el acto protocolario en el que el presidente de Colombia y el embajador de España reciben el pedido en Bogotá (Figura 16). Las cámaras captan, con planos abiertos, la llegada de las locomotoras y el edificio de Ferrocarriles de Colombia; y con planos medios y primeros planos, se muestra a los diplomáticos, reconociendo las máquinas y estrechando sus manos por el negocio pactado.

El narrador completa la información de lo que enseñan las imágenes, como los nombres y los cargos de las personas involucradas e incide en la alusión del "descubrimiento" con los nombres de las locomotoras: “(...) tres de ellas bautizadas con los nombres de las carabelas del descubrimiento y que forman parte de un pedido encargado a la industria española”.

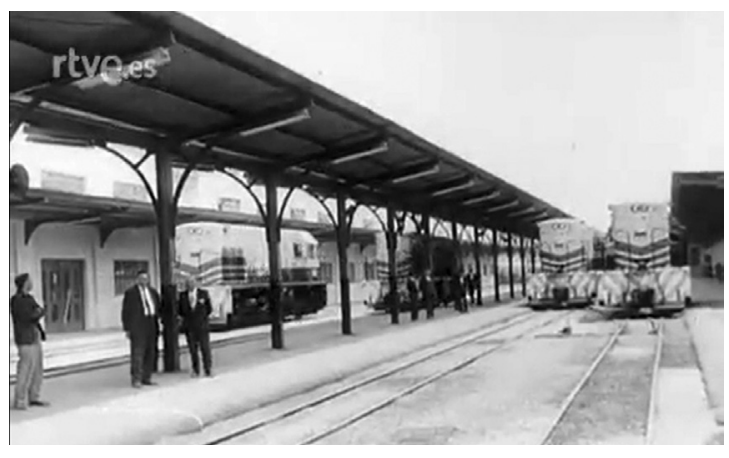

Figura 16. 
La nota está ubicada en la sección "informaciones" y menciona la fabricación de un buque español para Colombia (Figura 17). Se da cuenta de la venta del buque y se específican las características o potencia que tiene: "En los astilleros de Sevilla, ha sido botado el Ciudad de Manizales, un buque de 11750 toneladas, segundo de una serie construidos en dicha factoría, por un encargo de una naviera de Colombia (...)”. La música de fondo termina de darle el dinamismo y entusiasmo a la nota y marca el cierre de la información, mientras muestran el trabajo de los operarios y la grandiosidad del buque.

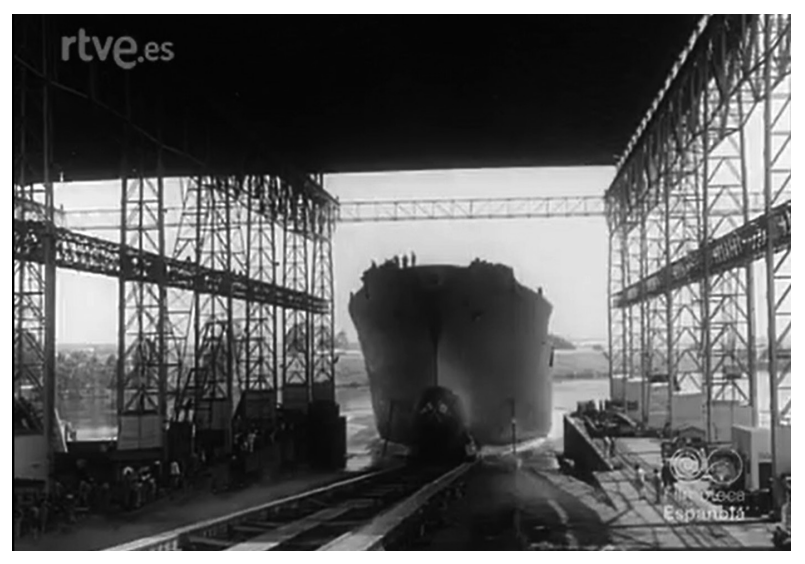

Figura 17.

\subsubsection{Observaciones generales del Bloque 2:}

En esta serie de siete capítulos, comprendidos en la década de los 60, se percibe una intención de cubrir noticias con temáticas y tendencias más económicas y que implican a Colombia como país favorecido por los avances de España. Siendo insistentes con el propósito bandera del NO-DO de mostrar el desarrollo de España impulsado por el Régimen, se propone una representación de Colombia como un país que requiere desarrollo y que acude a los avances y capacidades de la tecnología española para tratar de conseguirlo; pero que también es una nación que se encamina al progreso, que cuida de sus pobladores 'no civilizados' y que recibe la visita del presidente de los Estados Unidos.

Se privilegia al aparato productivo y distributivo, haciendo una distinción a la máquina y al producto; tanto la composición de las imágenes, como sus tamaños de plano, movimientos de cámara y su montaje con la música, los exaltan. 


\subsection{Bloque $\mathrm{N}^{\circ}$ : Colombia, nación meritoria y digna de cubrimiento mediático:}

Capítulo 12: $\mathrm{N}^{\circ}$ 1467-B (15-02-1971)

Nota sobre la inauguración de Expotur en Bogotá, por parte del embajador español en Colombia y el presidente colombiano Misael Pastrana Borrero. Se hace cubrimiento del acto oficial de apertura, pero también se registran algunas piezas de la exhibición. Además, se incluye un trozo de la presentación artística de Carmen Rojas y Paco Ruiz, que hace parte de la exposición. Como primera vez, acude a música diegética y se acopla con la música de fondo que sigue toda la noticia (Figura 18).

El narrador se involucra en la noticia y utiliza algunos adjetivos para completar la descripción del evento: "Tras un fervoroso elogio y saludo a España, el presidente de la república de Colombia, Misael Pastrana Borrero, inaugura en Bogotá la Expotur (...)”. Además, se refiere a Colombia como "nación hermana".

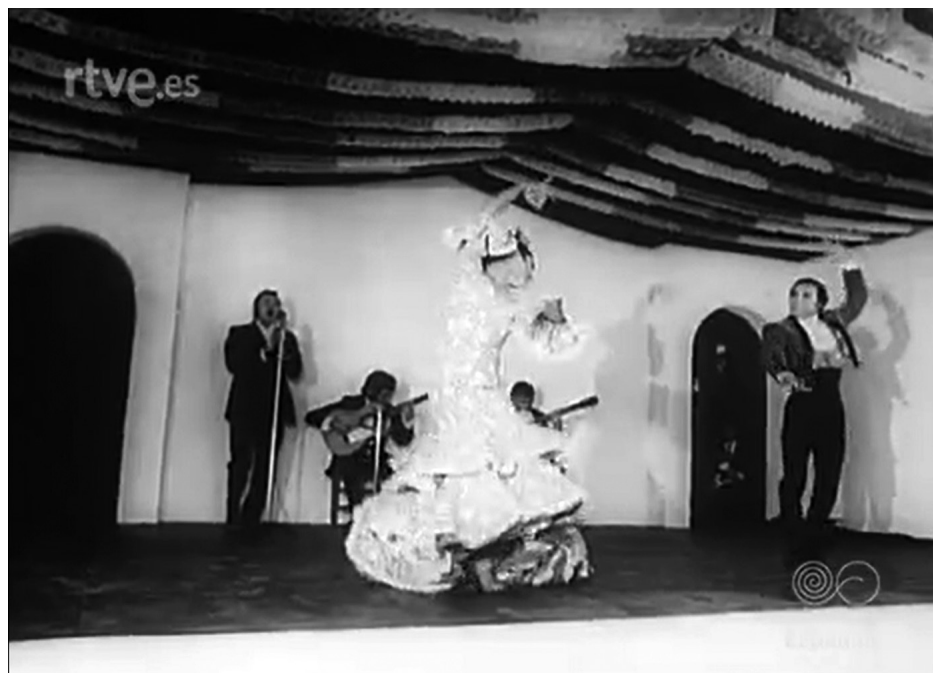

Figura 18.

Capítulo 13: $\mathrm{N}^{\circ}$ 1487-B (05-07-1971)

Contiene una nota de la visita del ministro español de Asuntos Exteriores a Colombia. Aprovechando su visita, la nota hace referencia a dos eventos que atiende el representante español: el homenaje a la memoria de Simón Bolívar (Figura 19) y el centenario de la Academia Colombiana de la Lengua (Figura 20). En los dos eventos advertidos, el discurso describe lo que comprende el evento: “(...) rindió homenaje a la memoria de Simón Bolívar, depositando una corona de flores ante el monumento que se alza en la quinta donde vivió" "En la Academia Colombiana de la Lengua, primogénita de las correspondientes de la Real Academia Española fundadas en América (...)”. 
También se da licencia para algunas interpretaciones y calificativos de lo que dicen los representantes como: "El señor López Bravo expresó la gran satisfacción que sentía al hallar vivos en Colombia los sentimientos de fraternidad con España”. La música es diferente en cada nota, pero ambas acompañan toda la noticia, con melodías lentas y con carácter épico.
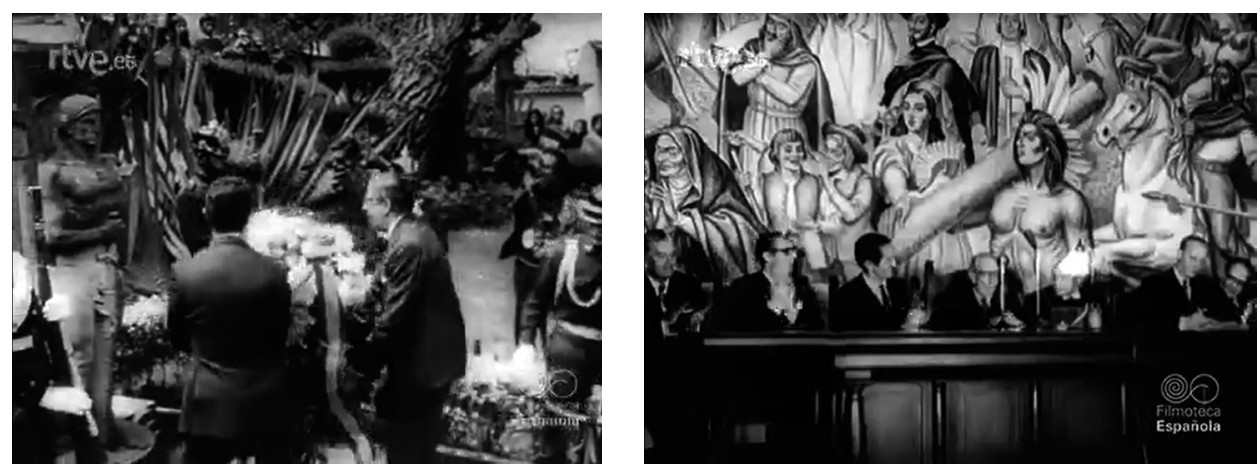

Figuras $19 \mathrm{y} 20$.

Capítulo 14: $\mathrm{N}^{\circ}$ 1702-A (25-08-1975)

El reportaje habla de España como destino escogido por iberoamericanos para adelantar sus estudios. Sin embargo, tiene dos momentos que componen todo el filme, con tintes y tratamientos diferentes. En primer lugar, se inicia con una voz en off que comenta cifras noticiosas sobre viajeros en España y un reportero que entrevista transeúntes en el aeropuerto de Madrid (Figura 21): "unos 400 mil viajeros procedentes de países hispanoamericanos, arribaron en 1974 (...). Su primer encuentro con la capital de España los hace descubrir sus muchas bellezas”. Indagando por el motivo de visitar territorio español y las procedencias, el reportero también se interesa preguntando: “¿Considera importante para un latinoamericano conocer España?”.

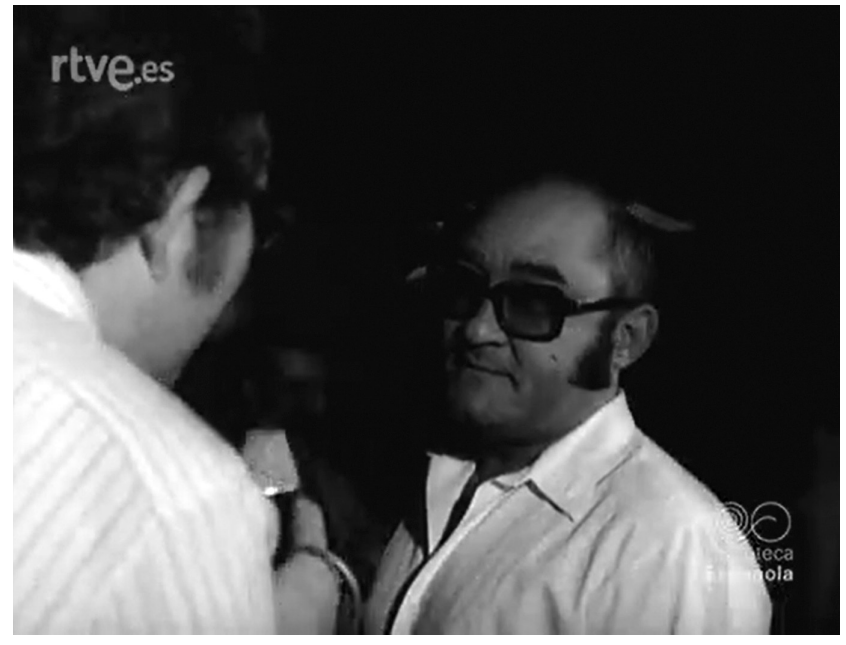

Figura 21. 
La segunda parte del reportaje continúa con el caso de una estudiante colombiana que llegó a Madrid a realizar estudios en la Universidad Complutense (Figura 22). Es narrado con la voz en off del narrador y la voz en off de la protagonista, en un diálogo que va contando la historia con preguntas y respuestas:

Voz en off de la mujer: "Me llamo Elizabeth Maldonado y he nacido en el barrio el Belalcázar, que es un barrio de Bogotá".

Voz en off del narrador: "Elizabeth es una de las muchas estudiantes iberoamericanas que ha hecho de Madrid su segunda patria. ¡Suerte, Elízabeth! Y que tengas una feliz estancia”.

Este bloque es un reportaje con estructura argumental que documenta el caso de la estudiante colombiana, pero en tono documental. Es decir, que se construye un guion y unos diálogos para dar cuenta de la vida de Elizabeth en Madrid y para exaltar a la ciudad como lugar ejemplar para ir a estudiar.

Con las imágenes y la música también se construye ese discurso. Selección de planos con nombres de establecimientos referentes a Latinoamérica, situaciones recreadas de estudiantes en bares, en las calles de la ciudad, reunidos estudiando e, incluso, una situación en la que se conocen dos personajes por tropezarse caminando. También las músicas con ritmos e instrumentos andinos, por ejemplo. Como elemento remarcable, se hacen muchos planos cercanos de las personas involucradas.

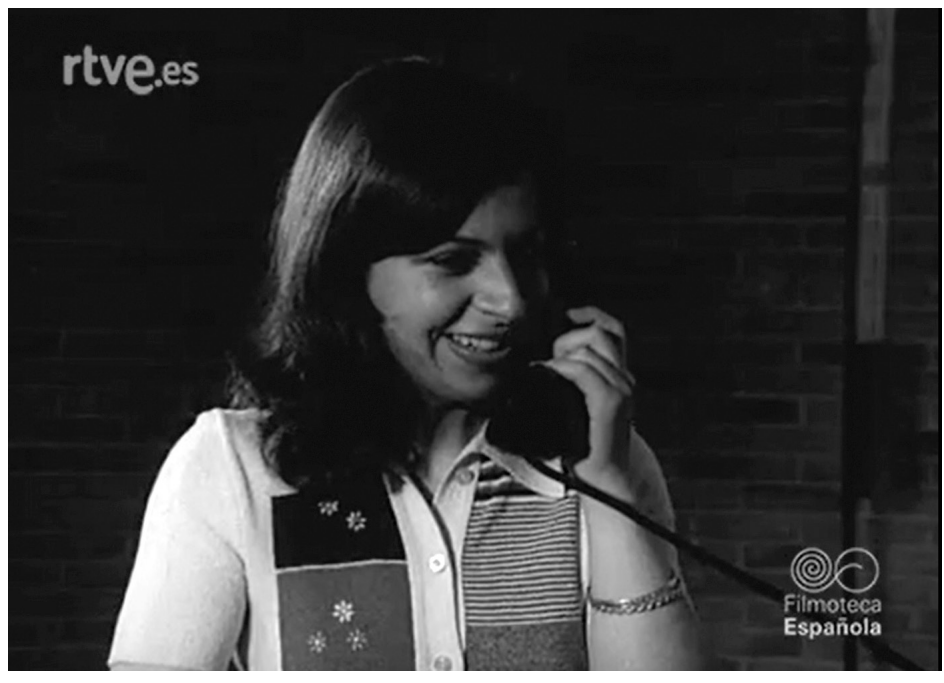

Figura 22.

Capítulo 15: $\mathrm{N}^{\circ}$ 1702-B (25-08-1975)

Titulada "Folklore iberoamericano", se registra una interpretación artística de una agrupación colombiana y una de un cantautor argentino, como celebración del $V$ Festival de la Rábida, España. Las imágenes a color, intercalando planos medios, generales y movimientos de zoom in, presentan el número de danza del Ballet de 
Colombia Sonia Osorio (Figura 23) y la interpretación musical de Horacio Guarany (Figura 24). Los protagonistas son los artistas y el sonido y la música son captados de manera directa y en sincronía con la imagen. Únicamente hay planos cortos contextuales al iniciar cada presentación.
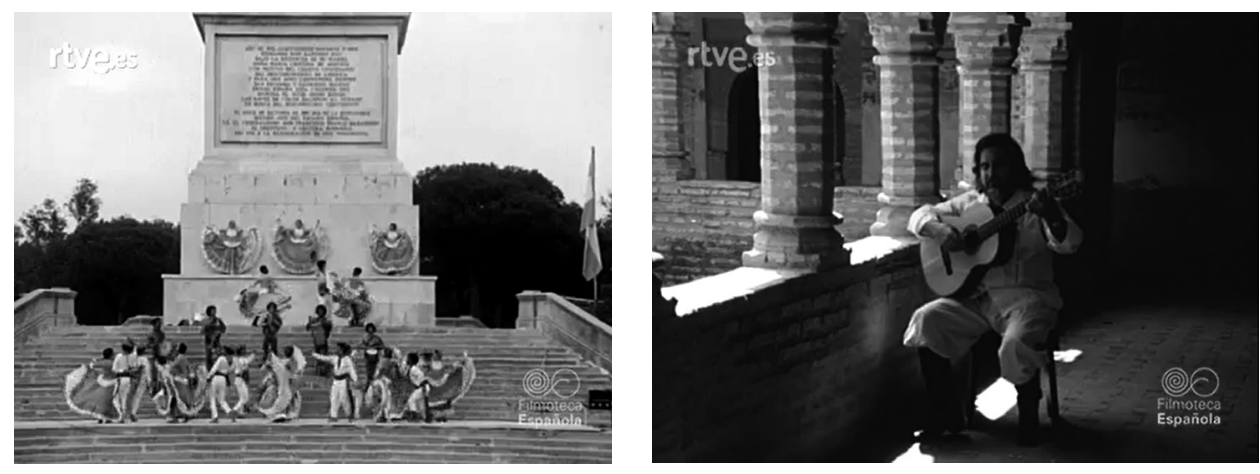

Figuras 23 y 24.

Capítulo 16: $\mathrm{N}^{\circ}$ 1707-A (25-09-1975)

Dedica los primeros dos minutos a la visita de los niños de la Operación Plus Ultra a Colombia y Venezuela. Bajo el rótulo de “informaciones y reportajes”, el filme hace una reseña de las experiencias que tuvieron los niños premiados, en su viaje a los dos países suramericanos. La noticia no hace mayor contexto de lo que significa la Operación, del motivo de la premiación, ni de la selección de los lugares visitados, pero sí deja manifiesto que visitar Colombia y Venezuela hace parte del premio entregado a los niños. También contiene elementos documentales de los sitios que visitan.

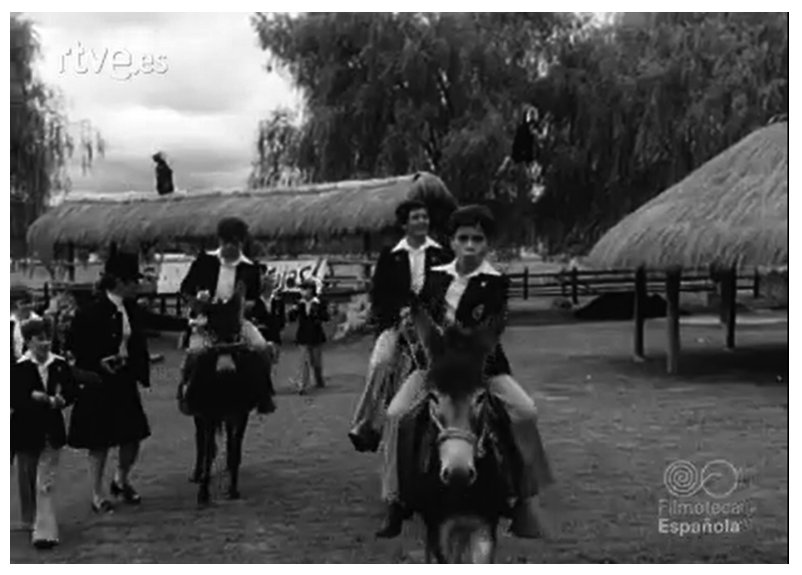

Figura 25. 
Las imágenes, aunque mayoritariamente se centran en los niños y en las actividades que realizaron en cada país (Figura 25), no se limitan a ello. La narración de la voz en off anuncia lo que las imágenes completan: "En el aeropuerto de Bogotá tuvieron una cariñosa acogida", "Durante su estancia en Colombia visitaron también la localidad de Silvia, pueblo típico situado en el Valle del Río Cauca, donde se reúnen los indios los días de mercado" (Figura 26). También la música, alegre y dinámica, acompaña toda la nota, y se utiliza música diegética y sonido directo ambiente, cuando se menciona la presentación artística ofrecida a los niños.

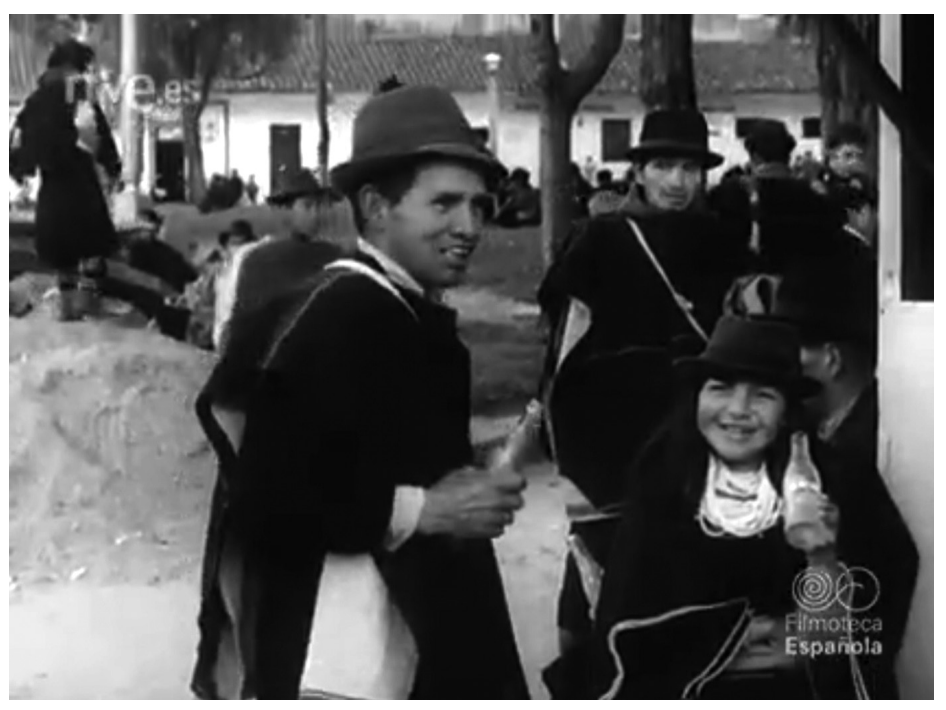

Figura 26.

Capítulo 17: $\mathrm{N}^{\circ}$ 1711-A (27-10-1975)

Titulado "Bogotá" (Figura 27), hace un retrato sobre la ciudad de Bogotá y sus monumentos. Centrándose en el legado colonial y sus mayores atractivos arquitectónicos, la nota documenta los vestigios de España en la capital colombiana. El reportaje explora imágenes exteriores y a color de Bogotá. Se hace un recorrido por calles de la ciudad, por edificios coloniales y por monumentos del legado español (Figura 28), por medio de planos generales, con movimientos de cámara que permiten contemplar el espacio y una música de ambientación lenta e instrumental.

El narrador también exalta y adorna las atractivas imágenes: "su catedral es una de las mejores del continente (...) la huella de España es una constante en la ciudad"e insiste en la presencia simbólica de España en la ciudad. 

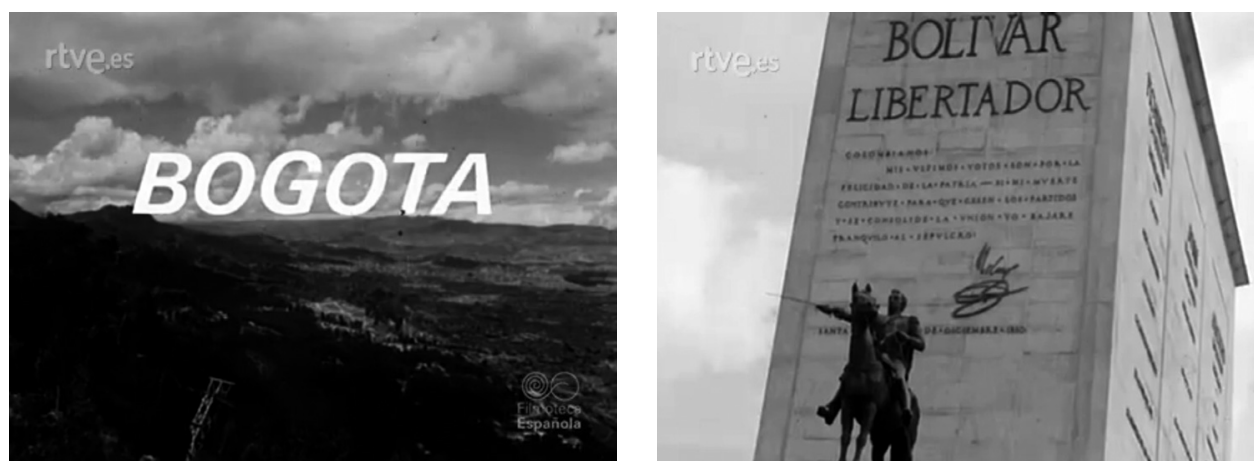

Figura 27 y 28 .

Capítulo 18: $\mathrm{N}^{\circ}$ 1723-B (02-02-1976)

Este filme, realizado a manera de reportaje, hace un recorrido por las exposiciones del Museo del Oro del Banco de la República de Colombia (Figura 29). Es una secuencia de imágenes a color que luego de mostrar el contexto y exterior del Museo en la ciudad, se adentra en las vitrinas y piezas de las exposiciones, con planos detalle y movimientos que muestran su dimensión (Figura 30).

El reportaje es un homenaje y un texto promocional de las piezas de oro prehispánicas. La narración en off también robustece la admiración: "hoy es la colección más grande en el mundo en su género, con un total de 14.000 piezas expuestas (...) La importancia del Museo del Oro de Bogotá, se debe tanto a su valor material, como al hecho de ofrecer a estudiosos e investigadores”; además proporciona información sobre algunas piezas (lo que son, su origen y quiénes las produjeron).
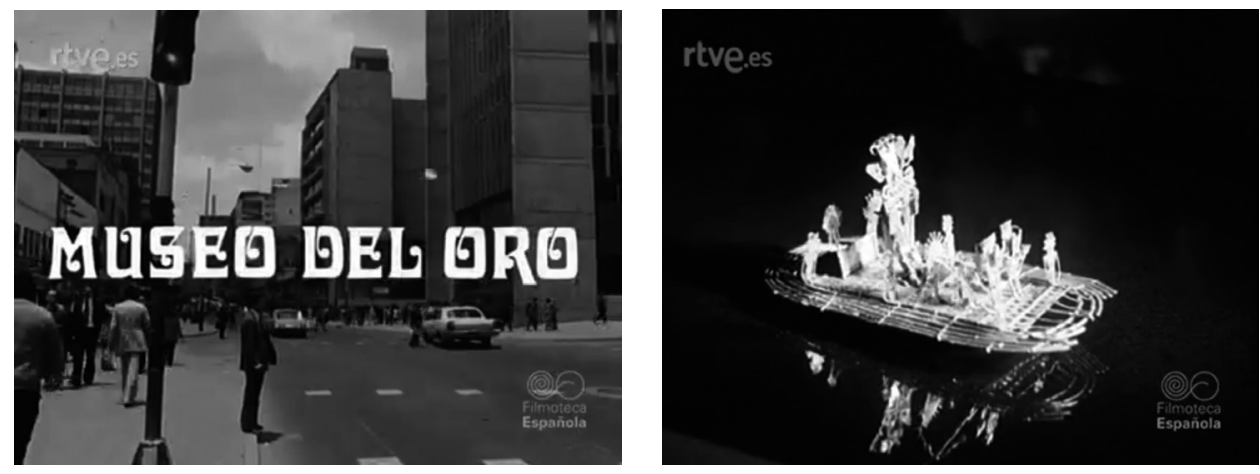

Figuras 29 y 30. 


\subsubsection{Observaciones generales del Bloque 3:}

Este último bloque abarca siete capítulos en los que se representa una Colombia meritoria y digna de cubrimiento mediático. Desde el punto de vista del país colombiano, es el período en el que tiene mejor figuración.

Esta representación no sólo se percibe en el tiempo que se dedica a los temas colombianos, sino en la manera en que se hace referencia al país y cómo se construyen sus notas. En cuanto a temáticas, todas incluyen aspectos positivos de la nación: desde ser lugar de visitas de personalidades españolas, pasando por ser elegida como destino de delegaciones españolas, tener jóvenes emprendedores, contar con lugares de interés mundial o tener paisajes dignos de fotografiar.

En términos de la forma, se destaca la presencia de música propia del tema abordado y la utilización de mezcla sonora entre sonidos extradiegéticos de ambientación (relacionadas con el tema) y sonidos captados en directo (por ejemplo, la música de Cumbia: Capítulo No 1702-B). También se da voz a nuevos elementos narrativos, como la inclusión de testimonios de entrevistados (estudiante colombiana: nota No1702-A), película a color y propuestas de reportajes con puestas en escena de actividades rutinarias.

\section{Consideraciones finales:}

El NO-DO contribuyó de manera significativa en la producción de ideas y preconceptos en un período relevante de la historia española y esto se puede ver en el interés de numerosos estudios y artículos que se preocupan por las relaciones y representaciones que se dan en su archivo (por ejemplo, la imagen de la mujer, las provincias españolas, el deporte, la iglesia o el régimen, entre otras temáticas). Parte de ese imaginario también influyó en la idea que se refleja del país colombiano y la manera como se representó para los espectadores que lo vieron.

Como hemos tenido ocasión de comprobar, el punto de vista de todos los filmes (exceptuando, tal vez, el del museo del oro $\mathrm{N}^{\circ} 1723-\mathrm{B}$ ), tiene siempre una perspectiva estatal española y responde a una mirada parcial y externa de las situaciones que relata. Nunca hay intervención de alguno de los involucrados en las notas y la única vez que interviene uno (nota de la estudiante colombiana en Madrid: $\mathrm{N}^{\circ} 1702-\mathrm{A}$ ), se incluye como una voz guionizada y ficcional, como voz en off.

La mayoría de las notas que se analizaron están construidas con elementos de una modalidad expositiva clásica, en la que la narración está mediada por una voz en off que se dirige al espectador y va guiando y comentando las imágenes que se muestran. La información y el discurso que presentan están construidos de manera lineal, con música que acompaña y ambienta las secuencias según su ritmo, pero sin manifestación voluntaria por evidenciar que lo que se presenta es información que 
pertenece a una mirada subjetiva de la realidad. Tampoco se le da voz o posibilidad de intervención a ningún actor (salvo en el reportaje de los estudiantes latinos $\mathrm{N}^{\circ}$ 1702-A o la visita del presidente Kennedy a Colombia $\mathrm{N}^{\circ}$ 992-C) y en sólo tres filmes se introduce música diegética o sonidos de registro directo $\left(\mathrm{N}^{\circ} 1467-\mathrm{B}, \mathrm{N}^{\circ}\right.$ 1702-B, $\left.\mathrm{N}^{\circ} 1702-\mathrm{A}\right)$. En ninguna ocasión se invita al análisis o se acude a fuentes diversas que presenten alternativas, sino que se guía todo el argumento con adjetivos, descripciones, aseveraciones o apreciaciones de la voz en off del narrador.

Haciendo una revisión en conjunto de todas las notas que el NO-DO dedica a Colombia o que hacen referencia en sus temáticas al país colombiano, este artículo propone la caracterización de tres momentos que reúnen, cada uno, notas con características similares tanto en su contenido como en la forma de construirlas cinematográficamente. Un primer momento, comprendido en la década de los 50, en el que se representa un país urgido de asistencias externas, golpeado por tragedias y desgracias y en el que sus gentes son grupos de personas que no se reconocen, habitantes en masa de zonas rurales, sin subjetividad.

Un segundo bloque, en los años 60, en el que Colombia es un país que solicita desarrollo económico y tecnológico a España y que demanda de los productos de una nación desarrollada para conseguirlo. Además, las autoridades políticas y las máquinas se llevan el protagonismo.

El último grupo, con fechas de los años 70, representa a Colombia como una nación que merece atención; un país digno de ser fotografiado y visitado, con atractivos mundiales y una relación muy cercana y activa con los gobernantes españoles. Este interés no queda explícito solamente en las temáticas que se abordan (Museo Nacional del Oro, estudiante colombiana en Madrid, atractivos de Bogotá, etc.), sino también con la inclusión de elementos y recursos cinematográficos novedosos, como música propia de la región geográfica de la que se habla, sonidos captados en directo, testimonios de personas entrevistadas y puestas en escena guionizadas, además de imágenes a color y planos cercanos de gentes a quienes se les menciona como individuos colombianos.

De esta manera, la representación de Colombia va surgiendo de una transformación cronológica y gradual en la que su imagen adquiere importancia y resulta más condescendiente, tanto desde lo discursivo o argumental, como en la forma y estructura cinematográficas.

Las notas con formato de reportaje, documental o crónica, gozan de mayor libertad creativa y de más recursos cinematográficos que enriquecen el texto, además de ofrecer una representación menos parcializada y con carga propagandística menos notoria. Lo anterior aclarando que los documentales del $N O-D O$ no contaban con exclusividad amparada por la ley, como sí la tenían los noticiarios. 
El archivo del NO-DO no es del todo público, pues no hay facilidad para hacer uso creativo de sus películas, además de no tener acceso libre a descargarlo en línea. Es posible acceder a él para analizarlo, reflexionar, cuestionarlo, describirlo, explicarlo y sugerir lecturas, sin embargo, pese a estar digitalizado y disponible en la web casi en su totalidad, sigue siendo un archivo oficial, controlado y administrado por la Filmoteca Española, la cual decide quién puede utilizar sus imágenes y con qué fines.

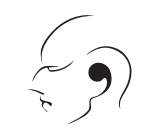

\section{Notas}

1 Este artículo es resultado de una investigación realizada para el trabajo final del Máster en Cinematografía, en la Universidad de Córdoba, España.

2 Comunicador social-periodista de la Universidad del Valle (Colombia), egresado del Máster en Comunicación y Educación Audiovisual, de la Universidad Internacional de Andalucía (España) y del Máster en Cinematografía, de la Universidad de Córdoba, (España). Cursó el Diplomado Internacional en Documental de Creación "Mirada de Dos Mundos", en la Universidad del Valle. Ha dirigido dos documentales ( Playa Mulatos y Generación Bienestarina), ganadores de distinciones y premios en festivales de cine y ha participado de diversas producciones audiovisuales como cortometrajes y largometrajes de documental y ficción, en roles de dirección de fotografía, sonido, fotofija y edición. También ha hecho parte de proyectos de educación e intervención social y se ha desempeñado como comunicador de diversas dependencias universitarias.

3 Plataforma disponible en el sitio web: http://www.rtve.es/filmoteca/no-do/ (activo en junio de 2018).

${ }^{4}$ La plataforma está disponible en la URL: http://www.rtve.es/filmoteca/no-do/

${ }^{5}$ Ana Melendo Cruz es docente del Máster en Cinematografía de la Universidad de Córdoba y Ph.D con Mención Europea en Historia del Arte.

${ }^{6}$ Ramiro Arbeláez Ramos es docente de la Universidad del Valle (Colombia) y magíster en Cine y Televisión de la Universidad de Sao Paulo (Brasil).

7 Frase célebre del cineasta, que además incluye en el portal de su sitio web: https://www. patricioguzman.com/es/

\section{Referencias bibliográficas}

Aumont, J. et Marie, M.: L'analyse des films, París, Nathan, 1988

Barrios S. P.: El testimonio audiovisual como herramienta de reconstrucción de la memoria colectiva frente a la transformación de las dinámicas cotidianas en un mundo globalizado, Revista de Estudios Cotidianos - NESOP, N³, Año 1, ISSN: 0719-1928, 2013 
Català, D., J.: El murmullo de las imágenes, Asociación Shangrila, Textos Aparte, ISBN: 9788493936686, 2012

Cervio, A. L.: Recuerdos, silencios y olvidos sobre "lo colectivo que supimos conseguir". Memoria(s) y olvido(s) como mecanismos de soportabilidad social, Revista Latinoamericana de Estudios sobre Cuerpos, Emociones y Sociedad, No 2, 2010

DITTUS B., Rubén: El cine documental político y la noción de dispositivo, una aproximación semiótica, Tesis Doctoral, Universitat Autònoma de Barcelona, Parte II, Diseño metodológico, 2012

DOMÍNGUEZ-DELGADO, Rubén y LÓPEZ-HERNÁNDEZ, María A.: La documentación fílmica: marco contextual histórico, Documentación de las Ciencias de la Información, Ediciones Complutense, ISSN: 0210-4210, 2016

FANDIÑO P., Roberto G.: La Rioja al alcance de todos los españoles. NO-DO y la reconstrucción de un discurso sobre la provincia. Instituto de Estudios Riojano, Logroño, 2009

FIBLA GUTIÉRREZ., Enrique: NO-DO- Archivo y secuestro de la imaginación, Icono 14, vol. 13, 2015

GAVALDÀ R., Josep; LLORCA, Germán; PERIS, B., Àlvar: Los modelos de representación del documental. Del cinematógrafo a los dispositivos digitales, Telos, 2013

GÓMEZ,T., Francisco: El análisis del texto fílmico, Castellón: Beira Interior, 2006

GUTIÉRREZ C., Andrés y AGUILERA, Camilo: Documental colombiano: temáticas y discursos. Colección trabajos de grado, Universidad del Valle, Colombia. 2002

HUESO, Ángel L: El cine y el siglo XX, Ariel, Barcelona, 1998

MARTÍNEZ, G. Fernando: La historia y el cine: ¿unas amistades peligrosas?, Vínculos de Historia, Num.2, 2013

MARZAL, Javier. y GÓMEZT., Francisco: Metodologías de análisis del film, Edipo, 2007

MARZAL, Javier. y GÓMEZ T., Francisco: Interpretar un film. Reflexiones en torno a las metodologías de análisis del texto fílmico para la formulación de una propuesta de trabajo, en I Congreso Internacional de Análisis Fílmico Universitat Jaume I, Ciclo de Otoño de comunicación Fundación General Complutense, Madrid, 2006 , disponible en: http://bit.ly/2g9oaXB

MATUD, J., Álvaro: La modalidad de representación de los documentales de NO-DO durante el primer franquismo (1943-1953), I+C Investigar a comunicación: Investigar la comunicación = Investigar la comunicació = Komunikazio-Ikerketa, ISBN:978-84-612-3816-3, 2008

NICHOLS, Bill: La representación de la realidad, Paidós Comunicación Cine, 1ra Edición, 1997

SÁNCHEZ B., Vicente y TRANCHE, Rafael, NO-DO El tiempo y la memoria. Cátedra, Filmoteca Española, Quinta Edición, 2002

SORLIN, Pierre: Cines europeos, sociedades europeas, 1939-1990, Barcelona, Paidós, 1996

VENTAJAS D. Fernando: Málaga en el No-Do (1943-1980), Isla de Arriarán, No 27, 187-222

\subsection{Video}

Una historia próxima. Programa especial 50 aniversario. (Televisión Española S.A) (2013) Madrid, España. [Disponible en http://www.rtve.es/filmoteca/no-do/historia/ [04/06/2017] Así es la web de la Filmoteca Española (Filmoteca Española S.A) (2015). [Disponible en http: / / www.rtve.es/noticias/20121220/archivo-filmoteca-no-do-mayor-fondo-historicoaudiovisual/590521.shtml]

Recibido: 09 de Abril de 2018 / Aprobado: 30 de junio 2018 